Hanne Mehli er stipendiat ved Institutt for fysikk, Norges teknisk-naturvitenskapelige universitet (NTNU). Hun har bakgrunn som sivilingeniør og forsker, og har de senere årene jobbet med undervisning i fysikk og fysikk fagdidaktikk ved NTNU, og som fysikklærer i videregående skole. Hun har også jobbet med etter- og videreutdanning for lærere innen fysikk og romteknologi.

Berit Bungum er førsteamanuensis ved Institutt for Fysikk, Norges teknisk-naturvitenskapelige universitet. Hun har faglig bakgrunn i fysikk og doktorgrad om teknologiundervisning i grunnskolen. Ved NTNU arbeider hun med fagdidaktikk i fysikk, naturfag og teknologi i lærerutdanning og forskning.

\title{
HANNE MEHLI
}

Institutt for fysikk, NTNU, Trondheim

hanne.mehli@ntnu.no

\section{BERIT BUNGUM}

\section{"Ingen kan bygge romferge alene" - Læreres utbytte av faglig etterutdanning innen romteknologi}

\begin{abstract}
This article reports a case study of how science teachers benefit from participation in an in-service course on space technology at Andøya Rocket Range in Northern Norway. The course deviates from current policy for teachers' professional development by being short-term, targeting individual teachers and by having a somewhat narrow subject focus. In this course, teachers work closely with space scientists and engineers, forming a community of practice in highly technological settings. The transfer of this experience to classroom teaching is clearly challenging. By means of in-depth interviews, we have investigated teachers' outcome from the course and how they see it benefiting their teaching. Results indicate three main categories of outcome: Affective outcome; content knowledge and practical skills; and technological process knowledge. This outcome is found to have an indirect, yet important, influence on the teaching of science that should be taken into account in policy for science teachers' professional development.
\end{abstract}

\section{INNLEDNING}

Mange studier viser at læreren er den viktigste faktoren for elevers læring, se for eksempel Hattie (2009). Kompetanseutvikling for lærere er derfor et viktig satsingsfelt i utdanningssektoren. I Norge lanserte regjeringen i 2002 strategiplanen "Realfag naturligvis" for å bedre realfagenes vilkår i alle trinn i utdanningssystemet (Utdannings- og forskningsdepartementet, 2002). Dette ble fulgt opp av strategiplanene "Et felles løft for realfagene" (Kunnskapsdepartementet, 2006) og "Realfag for Framtida" (Kunnskapsdepartementet, 2010). I alle disse planene står læreres kompetanse sentralt som satsingsfelt. Satsningen har vært i form av en desentralisert strategi der midlene i stor grad går til skoleeiere, det vil si de enkelte fylker og kommuner. Videreutdanning (som gir studiepoeng i universitetsog høgskolesystemet) gis prioritert framfor kortvarige etterutdanningstiltak. Målet med satsningen har vært å sikre kompetanseutvikling som dekker lokale behov og som dermed skal gi bedre forutsetninger for varige og praksisbaserte endringer. Dette kan imidlertid gå på bekostning av læreres mer spesifikke faglige utviklingsønsker (Hagen \& Nyen, 2009). 
Siden etter- og videreutdanning ofte er ressurskrevende, er det viktig å evaluere hvilket utbytte lærerne, og dernest elevene, har av ulike tiltak. I slik evaluering er det imidlertid viktig å ta høyde for at utbyttet kan være av ulik karakter for ulike typer av kurs, og å undersøke nærmere hva utbyttet består i for læreren som profesjonell yrkesutøver. Tradisjonelt har læreres etter- og videreutdanning bestått av kortvarige kurs med fokus på spesifikke emner eller arbeidsmetoder. I denne artikkelen beskriver vi en studie gjort av et kurs i denne tradisjonelle kategorien, et nordisk etterutdanningskurs i romteknologi ved Andøya Rakettskytefelt i Norge. Dette er et eksempel på et relativt kortvarig kurs som er bygd opp som en workshop med både forelesninger og praktisk arbeid, uten studiepoeng, og som ikke krever for- eller etterarbeid av deltagerne. Kurset skiller seg fra kompetansehevingstiltak som norske myndigheter nå i hovedsak satser på, ved at innholdet svært spesifikt og på et avansert faglig nivå, at det retter seg mot individuelle lærere og ikke til skolen som helhetlig organisasjon, og ved at mange av aktivitetene lærerne deltar på ikke uten videre synes å kunne overføres direkte til deres egen praksis i klasserommet. Har lærerne likevel et utbytte av kurset som forsvarer ressursene som brukes? På hvilke måter kan dette komme undervisningen deres og dernest elevene til gode? Hvilke effekter kan slike kurs ha, og med det, hva vil en gjennom nye tiltak satse seg bort fra? Med NTSC som case belyser vi gjennom en intervjustudie av lærere disse spørsmålene.

\section{Læreres kompetanse i naturvitenskapelige fag}

Læreres kompetanse utgjør en kompleks kombinasjon av faglig, didaktisk og pedagogisk kunnskap. Den innebærer innsikt i elever og deres læring og utvikling, skolen som organisasjon og undervisningens innhold. I naturfagene innebærer dette kunnskap om alle naturvitenskapens tre dimensjoner; naturvitenskap som produkt, prosess og sosial institusjon (Sjøberg, 2009). Lærerne må ha kjennskap til egne undervisningsfags relevans og plassering i samfunnet, kunne formidle nytte og nødvendighet av fagene i verden utenfor klasserommet og formidle hvilke muligheter elever som velger realfag har i videre utdanning og yrkesliv. Lærerutdanning kan ikke forberede lærere på alle disse områdene, verken kunnskapsmessig eller pedagogisk. Kompetanseutvikling for praktiserende lærere er nødvendig for at de skal kunne være oppdatert og bidra til utvikling av kunnskapssamfunnet.

Internasjonalt har det ofte blitt vist til at naturfagene i skolen er for innholdsfokusert, og lite relatert til fagenes arbeidsformer og relevans i samfunnet (se for eksempel Osborne \& Dillon 2008). Man har blitt opptatt av at undervisningen i større grad skal gjenspeile autentisk naturvitenskap (f.eks Roth, 1995), at den skal preges av undersøkende arbeidsformer (f.eks Abd-El-Khalick, m.fl., 2004), og gi elevene innsikt i naturvitenskapenes egenart som del av en naturvitenskapelig allmenndannelse (Schwartz, Lederman, \& Crawford, 2004). Dette stiller nye krav til lærerens egen innsikt i hvordan dagens naturvitenskap fungerer. Internasjonalt har derfor kurs og tiltak som skal gi lærere erfaring med realfag i autentiske sammenhenger blitt stadig mer populære. Vi har de senere årene sett mange eksempler på at lærere og lærerstudenter har deltatt i ulike forskningsfellesskap og jobbet sammen med forskere i reelle forskningsprosjekt (se Sadler, Burgin, McKinney, \& Ponjuan, 2010 for en oversikt). Felles for mange av disse studiene er at kursdeltagerne tar del i et autentisk praksisfellesskap, benevnt på engelsk som "community of practice" (Lave \& Wenger, 1991). I slike praksisfellesskap samarbeider deltagerne aktivt om å løse felles oppgaver, med læringsutbytte som reflekterer både kunnskapsfeltets natur og kulturelle normer (Wenger, 1998). Deltagerne får erfaring med omgivelsene som virksomheten hører hjemme i, og opplever også denne erfaringen og eget engasjement som meningsfull. Innen utdanning er slike prosesser basert på faktisk deltagelse sett på som effektive for læring, noe vi ser gjennom tradisjonen for lærlingeordninger innen håndverksfag.

Ideen om praksisfellesskap har også relevans for etter- og videreutdanning for lærere. Sadler m.fl (2010) fokuserer nettopp på effekt av aktiv deltagelse i praksisfelleskap i sin oversikt over tiltak som tar sikte på å gi lærerne erfaring med reell naturvitenskap. Involvering i et praksisfellesskap kan bidra med fruktbare læringsmiljø der deltagerne oppnår innsikt i ulike aspekter av vitenskapelig eller teknisk arbeid, lærer om metoder og verktøy og bruker kunnskap i autentiske situasjoner. Autentisk 
vil her si aktiviteter som sterkt ligner på de aktivitetene som faktisk utføres i en spesifikk profesjonell sammenheng. Sadler m.fl. konkluderer med at for å være effektive må tiltakene være langvarige, og at sannsynligheten for å lykkes øker med varighet og kontakttid med forsker. De peker på at fokus i hovedsak har vært på læreres innsikt i forskningsprosessen og naturvitenskapelig metode, der deltagerne skal planlegge og gjennomføre egne undersøkelser. Dette er i tråd med vektleggingen av undersøkende arbeidsmetoder i undervisning av naturfagene.

\section{Forskningsfokus}

Videreutdanningstilbud i form av kortere workshops og seminarer eksisterer og etterspørres av lærere, selv om dette i noen grad bryter med de strategier og anbefalinger som er beskrevet i innledningen. I denne studien undersøker vi hvilke kvaliteter slike tilbud faktisk har for lærere ved å bruke Nordic Teachers Space Camp (NTSC) ved Andøya rakettskytefelt som case. Dette er et kortvarig kurs med fagspesifikt innhold som hovedsaklig er basert på individuell deltagelse. Kurset gir innsikt i bruk av realfag utenfor skolen, men lærerne deltar imidlertid ikke i aspekter av forskning som ofte er vektlagt innen utforskende arbeidsmåter slik som formulering av problemstillinger og utvikling av metoder for undersøkelser. Det tar i liten grad for seg hvordan det relativt avanserte innholdet skal kunne overføres til elevene i klasserommet, men er likevel meget populært blant lærere. Hensikten med undersøkelsen er å belyse utbyttet lærere får av å delta på et slikt kurs i et lengre tidsperspektiv og hvordan dette i neste omgang kan ha betydning for deres undervisning og dermed for elevers læring og motivasjon for realfag.

Forskningsspørsmålene er:

- Hvordan vurderer lærerne sitt utbytte av å delta på et teknisk rettet kurs på et rakettskytefelt, og hva består dette utbyttet i?

- Hvilken effekt kan denne type kurs ha for lærernes egen undervisning og elever i skolen?

\section{Nordic Teachers' Space Camp}

NTSC er et initiativ hvor lærere får delta i et høyteknologisk naturvitenskapelig arbeidsmiljø sammen med ingeniører og forskere. Hvert år i august deltar ca 20 lærere på dette kurset på Andøya Rakettskytefelt (ARS) i Norge i regi av Nasjonalt Senter for Romrelatert Opplæring (NAROM). Kurset er åpent for deltagere fra hele Norden, men hovedtyngden av deltagere er fra Norge. NAROM er lokalisert sammen med ARS på Andøya, en øy på Nordlandskysten. Til sammen utgjør de et høyteknologisk og internasjonalt forskningsmiljø. Som deltagere på NTSC får lærere en introduksjon til moderne romteknologi, atmosfærefysikk og romforskning i dette forskningsmiljøet. Hensikten med sommerkurset er gjennom praktisk anvendelse av fysikk, matematikk og teknologi å øke interessen for, og i større grad ta i bruk, romrelaterte emner og teknologi i skolen.

NTSC er organisert som en camp av fem dagers varighet. ARS har sin egen hotellavdeling der kursdeltagere, forelesere og andre gjester bor under kurset. Hovedaktiviteten på kurset er å planlegge, tilrettelegge og avfyre en studentrakett. Til sammen bruker deltagerne halve kurstiden på forelesninger, øvinger og gruppearbeid tilknyttet rakettoperasjonen. I tillegg følger de forelesninger og laboratorieaktiviteter i andre relaterte emner. Forelesninger holdes hovedsaklig av eksterne forskere mens praktiske aktiviteter som magnetfeltmålinger, UV-målinger og rakettmotortesting ledes av ansatte ved NAROM. Selve rakettoperasjonen er organisert som gruppearbeid der fem grupper jobber med ulike gjøremål som alle er nødvendige for å kunne komme i mål med rakettoppskytingen. Hver arbeidsgruppe har hvert sitt ansvarsområde og består av fire lærere og en gruppeleder fra NAROM (forsker eller ingeniør). Rakettgruppa har ansvar for raketten, modellere flukt og forberede oppskyting, inkludert det å organisere oppskytingstillatelser fra flyplass og brannstasjon. Andre grupper har ansvaret for å lage sensorer og tilpasse disse til raketten, og for telemetri og signalbehandling. Selv om gruppene har ansvaret for hver sine arbeidsområder er det essensielt med samarbeid mellom grup- 
pene mot sluttfasen, bl. a for å teste sensorer, mottak av signaler, plassering av sensorer i rakettens lasterom m.m.

Evaluering gjennomført av NAROM ved kursavslutning viser at lærerne er svært positive til kurset og kursutbyttet (Mehli, 2008). Gjennom denne studien ønsker vi å få bedre innsikt i hva dette utbyttet består i, hvilke erfaringer lærerne ser på som positive og viktige, og hvilke faktorer ved et slikt kurs som anses som viktige av deltagerne.

\section{METOdE}

Studien er bygd opp som et multippelt kasus-studium som tar i bruk multiple kilder (Robson, 2002). Observasjon og skriftlige kilder i form av kursevaluering og spørreundersøkelser ved kursstart danner utgangspunktet for en intervjuundersøkelse. Intervjuundersøkelsen er basert på dybdeintervjuer med fire lærere der hver lærer blir behandlet som et enkelt del-kasus av studien. Dette er hensiktsmessig når formålet er å utvikle en dypere forståelse av hvordan en type kurs gir effekt blant lærere som deltar (Robson, 2002). Et interpreterende kasus-studium som dette er valgt for å kunne utdype nærmere hva utbyttet lærerne rapporterer består i, og belyse så mange aspekter av dette som mulig (Merriam, 1998). I denne artikkelen fokuserer vi kun på intervjuene i undersøkelsen ettersom andre deler av studien er beskrevet andre steder (Mehli, 2008; Mehli \& Bungum, 2012).

\section{Informanter}

De utvalgte lærerne deltok på NTSC i august 2009. Alle kursdeltagerne dette året ble bedt om å svare på et spørreskjema ved kursets oppstart der de blant annet ble spurt om bakgrunn, erfaring, motivasjon for å delta og hva de ønsket å få ut av kurset. Lærernes svar dannet grunnlag for utvalg av informanter til intervjuene. Alle kursdeltagerne ble spurt om de kunne tenke seg å være med i undersøkelsen. Av de som sa seg villig til å delta ble fire lærere fra videregående skole valgt ut. Utvalget var selektivt med mål om størst mulig variasjon i bakgrunn og erfaring. Av praktiske årsaker ble kun norske lærere med i intervjuundersøkelsen. Innenfor gruppen av lærere vi hadde til rådighet ble det gjort en "maximum variation sampling" (Robson, 2002). De valgte informantene hadde mellom 2 og 30 års erfaring som lærere, jobbet innenfor ulike studieprogram i videregående skole, både studiespesialiserende og yrkesfaglige studieretninger, og på ulike steder i Norge.

\section{Intervjuene}

Intervjuene var semi-strukturerte og ble gjennomført 6-8 måneder etter avsluttet kurs. Vi ønsket å høre lærernes oppfatninger relatert til noen hovedtemaer. Disse hovedtemaene inkluderte motivasjon for å delta på NTSC, hvilke tidligere erfaringer de har med kompetanseutvikling og deres oppfatning av dette, hva de så som sitt viktigste utbytte av kurset og hvordan de ser mulighetene for å overføre dette til egen undervisning med elever.

Disse temaene ble valgt ut på grunnlag av tidligere undersøkelser (Mehli, 2008), ut fra spørreundersøkelsen gjennomført ved kursets oppstart og ut fra NAROM sin egen kursevaluering rett etter kursavslutning. Hensikten med undersøkelsen var å se på hva slags utbytte lærerne mente de fikk og hvordan de opplevde at de kunne utnytte dette. Det var derfor vesentlig å fokusere på hva som fungerte for deltagerne, hva som gjorde kursopplevelsen bra, hvordan de lærte underveis og tok med seg kunnskap og erfaringer videre. Intervjuene tok også delvis utgangspunkt i samtaler og spørreundersøkelse gjennomført under selve kurset. Dette for å høre hvordan utbytte og erfaringer var i forhold til det de hadde forventet seg da de meldte seg på, og for å ta opp problemstillinger som kom fram under kurset. 


\section{Analyse}

Analysen ble gjort i to trinn, tilsvarende et multippelt kasus-studium (Merriam, 1998). Dette innebærer at intervjuene først ble analysert enkeltvis med den enkelte lærer som analyseenhet ("within-case analysis"). Dette ble gjort for å lære mest mulig om den enkelte informant og kurserfaringene for hver enkelt, og for å kunne gi et bedre bilde av hver enkelts bakgrunn. Deretter ble dataene analysert på tvers av kasusene ("cross-case analysis") for å finne fellestrekk og variasjoner i informantenes opplevde utbytte og erfaringer.

Intervjuene ble analysert og kodet i en iterativ prosess med aspekter av konstant-sammenlignende metode ("Constant comparative method", Merriam 1998). Denne metoden er anvendelig nettopp i slike tilfeller der vi ønsker en induktiv utvikling av kategorier, men uten å ha ny teori som mål. Kategoriene ble konstruert gjennom en kontinuerlig sammenligning av informantenes utsagn om ulike hendelser, utbytte, opplevelser og årsaker til utbytte. Gjennom å stadig sammenligne enkeltdata med hverandre fant vi fellesnevnere som gikk igjen hos alle informantene. Utsagn som hadde fellestrekk i innhold eller årsak ble etter hvert kategorisert sammen i en iterativ prosess der kategoriene ble stadig færre og mer overordnet. Fra dette utkrystalliserte det seg tre hovedkategorier av utbytte som gikk igjen hos alle informantene. Disse hovedkategoriene inneholder ulike aspekter av hva slags utbytte lærere kan ha av å delta på denne typen kurs. På tilsvarende måte ble ulike konsekvenser og muligheter for overføring til lærernes egen undervisning samlet $\mathrm{i}$ to hovedkategorier. Gjennom å beskrive hovedkategoriene kan vi her få et bilde av potensialet av slike kurs, hva slags erfaring lærere kan få og på hvilke måter disse erfaringene kan ha effekt for lærernes egen undervisning i ettertid.

\section{RESULTATER}

I denne delen presenteres resultatene fra intervjuene med lærerne. I første omgang presenterer vi informantene som enkeltlærere med deres bakgrunn og motivasjon for å delta på NTSC. Dernest presenteres resultatene ut fra de hovedkategoriene som induktivt kom fram under "cross-case" analysen når det gjelder lærernes opplevde utbytte av kurset og hvordan de mener dette har effekt på egen undervisning.

\section{Lærerne}

\section{Niels - Målrettet entusiast}

Niels har vært lærer i 18 år, hovedsakelig i kjemi, matematikk og prosessfag. Motivasjonen for å delta på Nordic Teachers Space Camp kom i første omgang fra behovet for å lære fysikk. Han er generelt entusiastisk og elevfokusert, motiveres av problembasert læring og synes det er spennende å bruke faget til å løse praktiske problemstillinger. Dette vises også i de utfordringene han ønsker å gi elevene:

"Hvis vi skal sende opp en rakett og vite hvor høyt den farer og sånne ting så må man faktisk bruke faget for å finne det ut. Man snur litt på problemstillinga i fagene da. Altså, hva må vi lære for å finne ut av dette her?"

Niels skiller mellom den formelle, faglige kompetansen og undervisningskompetanse. Deltagelse på et kurs som NTSC mener han bidrar til økt faglig kompetanse, men også til det Niels kaller undervisningskompetanse. I dette legger han det å kunne variere undervisninga, synliggjøre fagets relevans, inkludere praktiske aktiviteter i undervisningen og på den måten gjøre faget mer spennende. Han legger stor vekt på nytten av å få innsikt i en teknologisk, forskningsrettet prosess:

"På forhånd så jeg for meg at vi skulle skyte opp en rakett og så skulle vi sikkert regne ut hvor høyt den gikk og sånne ting. Tenkte at dette ble jo bare lek, ikke noe fag i det. Og jeg måtte bite det kraftig i meg, for her var det mer fag enn jeg noen gang kunne svelge!”

Niels er nøktern i forhold til hva som kan gjenskapes i skolen med egne elever, men mener at erfaringen han sitter igjen med er viktig å ta med inn i klasserommet. 


\section{Marie - yrkesrettet med spesifikk faglig interesse}

Marie har utdanning og jobberfaring som montør og ingeniør. Hun har nå jobbet som lærer i 8 år og underviser på yrkesfaglig studieretning. I hennes fag er det hele tiden teknologisk utvikling, og Marie søker stadig faglig påfyll og oppdatering på det hun føler hun kan minst om. Faglig kunnskap er viktig for hennes trygghet som lærer. Hun mener det er sterk sammenheng mellom motivasjon for å undervise og faglig kompetanse, og for å klare å engasjere elevene.

Egen interesse og lyst til å lære mer om telemetri og satellittkommunikasjon var hennes viktigste motivasjonen for å delta på NTSC. Marie ønsker å påvirke elevene til å bli mer interesserte i satellittkommunikasjon. De andre emnene de var innom underveis på kurset var hun mindre opptatt av. Hun likte å være på et kurs der alle deltok frivillig og i ferien, og der alle var avhengige av hverandre slik at alle måtte prestere underveis. Kurset ble oppfattet som intenst og arbeidssomt, men også engasjerende og faglig givende:

”Det var jo uvanlig for oss som er lærere. Å sitte på skolebenken, en hel dag, få alle de tingene, det bare pepret jo inn!"

Hun kunne godt tenkt seg enda større faglige og tekniske utfordringer underveis, for eksempel når det gjaldt styring av antennene de brukte for å hente ned signaler fra raketten.

\section{Albert - Den erfarne fysikklæreren}

Albert har jobbet som lærer i fysikk, naturfag og matematikk siden han var ferdig utdannet for 30 år siden. I forhold til etter- og videreutdanning er han faglig orientert. Motivasjonen ligger i å øke faglig kompetanse innenfor et emne av egen interesse. Han peker på at tilbudet innen etter- og videreutdanning for fysikklærere er begrenset, men han føler seg heldig som har fått mulighet til å delta på det som har blitt tilbudt.

Albert har et nøkternt forhold til utbytte fra kursvirksomhet og mener at utbyttet av kurs forsvinner fort. NTSC ble oppfattet som et bra kurs selv om han opplever telemetri og databehandling, som han jobbet med der, som lite matnyttig i forhold til de fagene han underviser. Han ser likevel nytten av delta på etterutdanning for å kunne utvikle og forsterke eksisterende kunnskap, og trekker fram den personlige gode opplevelsen på NTSC:

"Alle kurs får man noe igjen for, men det er vanskelig å plukke ut hva det er. For det kommer drypp som gjør at du lærer ting bedre. Veldig ofte kan du jo ting fra før men det kommer liksom innspill som gjør at du kanskje får en litt dypere forståelse av det du kunne. Og sånn var det vel her ved NTSC også, men her fikk jeg litt større drypp."

Noe av det han opplever som mest nyttig i ettertid er å ta med seg små historier, anekdoter tilbake til skolen for å kunne gjøre undervisninga mer levende.

\section{Lise - Nykommeren}

Lise har jobbet som lærer i to år, for det meste i fysikk. Hun underviser også IB (International Baccalaureate) og liker at elevene her utfordrer henne litt mer. Lise ser stadig etter nye metoder og innfallsvinkler hun kan ta med seg inn i klasserommet.

Hun er sosialt orientert og opptatt av ressursdeling for å utvikle seg som lærer, og å utvksle ideer, arbeidsmåter og konkrete ressurser med andre lærere. Motivasjonen for å delta på NTSC var i stor grad egeninteresse. Lise har alltid vært interessert i verdensrommet og romteknologi. Hun synes det er spennende å selv ha vært på Andøya Rakettskytefelt:

”Du blir jo fascinert når du får lov til å komme inn i et miljø som er stengt, egentlig. Det å få lov til å kikke inn. Det er det som er fascinasjon." 
Siden hun deltok på NTSC mener Lise at hun først og fremst har delt erfaringene sine med andre i form av begeistring over noe hun opplevde som spennende og profesjonelt.

\section{Hvilket utbytte mener lærerne de har hatt?}

Utbytte fra kurset omtaler lærerne på ulike måter. Den ene hovedkategorien som utpeker seg dreier seg om "Affektivt utbytte". Faktorer som selvtillit, motivasjon og inspirasjon hører til i denne kategorien.

Den andre hovedkategorien er utbytte i form av kunnskap. Alle lærerne omtaler de samme læringsutbyttene, men de legger ulik vekt på hva og hvordan de har lært. Marie og Albert fokuserer mest på den konkrete kunnskapen de făr med seg fra kurset. Dette omfatter formell, faglig kunnskap om f.eks satellitter og satellittbaner, atmosfærefysikk, rakettmotorer og mekanikk, men også praktiske ferdigheter som lodding og håndtering av teknologi. Lærerne selv omtaler dette som to sider av samme sak som begge gir faglig kompetanseheving. Dette har vi kategorisert som "Produktkunnskap og praktiske ferdigheter".

Teknologi, både som kunnskap innen moderne naturvitenskap og som prosess er en viktig del av NTSC og av det lærerne peker på som utbytte av kurset. Noen av lærerne fokuserer på utbytte i form av kunnskap om og erfaring med prosesser. Denne typen kunnskap skiller seg fra den formen for prosesskunnskap som handler om naturvitenskapens prinsipielle prosesser og metode - om observasjoner og tolkninger og vurderinger av disse (Sjøberg, 2009). I denne sammenhengen omtaler lærerne den innsikten kurset har gitt dem inn i en verden av forskning og teknologi de ikke kjente til fra før. Her vektlegges det å lære om hvordan kompliserte teknologiske prosesser foregår, få innsikt i den komplekse kunnskapen og det faglige samarbeidet som må til for å lykkes, og få forståelse for hvor mange biter som må på plass før f.eks en forskningsrakett kan fyres av og gi måleresultater tilbake. Vi velger derfor å kategorisere dette som "teknologisk prosesskunnskap".

I det følgende utdyper vi hva de tre hovedkategoriene består i, med utgangspunkt i data fra lærerintervjuene.

\section{Affektivt utbytte}

Alle lærerne trekker fram den gode opplevelsen som viktig, det å ha vært med på et godt opplegg på et flott sted, med god mat og hyggelige folk. Dette er faktorer som virker inn på totalopplevelsen.

De mest tydelige formene for affektivt utbytte er selvtillit, mestringsfølelse og økt faglig selvtillit. Dette var særlig et viktig utbytte for Marie og Lise. Marie er opptatt sin egen rolle under selve rakettoperasjonen og hvordan hun behersket jobben hun skulle gjøre:

"...de sa jeg hadde fått bedre måleresultat enn de som styrte de andre antennene... Så det var motivasjonen min. Jeg hadde gjort en god jobb!”

For Lise var økt faglig selvtillit det aller viktigste utbyttet. Under den praktiske delen av forberedelsene til rakettoperasjonen måtte hun ta tak i oppgaver hun ikke mestret tidligere, som for eksempel lodding av kretskort til raketten.

”Jeg kunne faktisk få til å sette sammen det kretskortet. En sånn liten ting, men bare... For det er lett når du er lærer og tenke at du egentlig er en sånn der teoretiker som bare suller rundt og ikke egentlig vet hva verden er."

Hun reflekterer videre over utviklingen fra å være tilskuer, som i starten, og til etter hvert få mer og mer ansvar.

”Du føler deg jo veldig liten når du sitter der med de som jobber der og som egentlig vet hva det går 
i. Det er jo ikke sånn at du føler deg på lik linje. Men samtidig så har du noe å svare for. Det hjelper ikke å være lektor hvis jeg ikke har gjort den jobben jeg skulle gjøre i verkstedet.”

Lærerne ble satt til oppgaver de i utgangspunktet ikke behersket, men som de etter hvert løste i grupper og under veiledning. Dette ga en god opplevelse av mestring underveis:

”Noen har liksom tro på at det her kommer jeg til å få til, også gir de meg oppgaven, også gir de meg hjelp til faktisk å komme dit. Det føltes bra." (Lise)

Den gode opplevelsen, mestringsfølelse og økt selvtillit faglig og praktisk fører til motivasjon og inspirasjon. Alle fire legger vekt på at det var morsomt å være på kurs og at kursopplevelsen både har gitt dem generell økt motivasjon for å undervise, og også økt motivasjon for å undervise de emnene de har jobbet med underveis. Både Niels og Albert mener kurset ga dem inspirasjon til å ta med stoff om raketter i undervisningen, og motivasjon til å gå grundigere til verks med fagområdet enn de ellers ville ha gjort.

\section{Produktkunnskap og praktiske ferdigheter}

Alle de fire lærerne mener de faglige utfordringene de møtte var spennende, og at de har fătt større faglig kompetanse. Dette gjelder uavhengig av at lærernes bakgrunnskunnskap er forskjellig. Det å ha anledning til å fordype seg og bruke tid på egen læring blir nevnt som vesentlig. Albert snakker blant annet om hva dette gjorde for hans forståelse av signalbehandling, et område han fra før kjente lite til:

"Plutselig så skjønner jeg jo hvordan den her signalbehandlinga fungerer. Og at hvis du adderer mange sånne sinuskurver så kan du få til akkurat den kurven du vil, og til og med få en sånn firkantkurve. Og dermed følte jeg det ble veldig nyttig for min del.”

Generell faktakunnskap blir også nevnt som viktig utbytte. Dette gjelder særlig kunnskap om teknologi knyttet til satellitter og romteknologi. For Marie var det viktigste utbyttet mer kompetanse innen telemetri og satellittkommunikasjon. Hun opplevde at hun fikk det hun ønsket seg, og fikk dekket sine faglige behov i forhold til egen undervisning. Lise nevner lodding av kretskort som et konkret utbytte, en praktisk ferdighet hun ikke hadde erfaring med fra før. I etterkant har dette vist seg å være verdifullt i forhold til egen undervisning innen grunnleggende elektronikk og sensorteknikk.

\section{Teknologisk prosesskunnskap}

Erfaring med og innsikt i en teknologisk prosess fremheves som et viktig utbytte for de fire lærerne, og det som i størst grad gjorde at kurset ble en god opplevelse. Det lærerne er særlig opptatt av er den innsikten de har fătt om kompleksitet, betydningen av fagkunnskap og samarbeid samt at praktiske løsninger er viktige å fokusere på selv i en høyteknologisk prosess. Niels og Lise fremhever den teknologiske prosesskunnskapen som det viktigste de sitter igjen med etter kurset. De nevner særlig innsikt i de faglige utfordringene som finnes i en slik prosess og at de har lært mye om problemstillinger og utfordringer.

”Når man begynner å gå inn i sånne ting som det der, så oppdager man hvor mange problemstillinger som dukker opp som man ikke har noen slags anelse om kan eksistere!”. (Niels)

Lise mener hun forstår mye bedre hva som foregår i en forskningsinstitusjon og opplever det som viktig å ha vært en del av prosessen selv. Mens hun tidligere så slike prosesser utenfra fikk hun nå se hva som foregikk "bak kulissene”. Hun likte å få faglige utfordringer og muligheten til strekke seg enda lenger:

”Du forstår det veldig mye bedre selv, hva som skal til, tror jeg. Når du må gjennom prosessen selv og ta del i det."

Kompleksiteten gjorde det nødvendig å samarbeide og deltagerne fikk god innsikt i den enkeltes betydning for å løse sammensatte tekniske utfordringer. Selve rakettoperasjonen ble av Marie oppfattet 
som "kjempekjekk", nettopp fordi deltagerne ble så engasjerte selv. Betydningen av samarbeid, at alle brikker var avgjørende for et godt resultat var en viktig erfaring:

"Det var jo og veldig spennende å vite at det er så lite som skal til, fra alle gruppene. Hvis ikke alle gjør jobben sin godt så går det ikke."

Følelsen av å være betydningsfull for det felles prosjektet var altså vesentlig. Albert mente også at samarbeidet deltagerne i mellom, og det å få innsikt i hvor viktig dette er var verdifullt:

"En fikk innblikk i en sånn stor operasjon hvor alle gruppene var avhengige av hverandre og ingenting kunne starte før alle hadde fått til sin del. Og da, det er klart, alle skjerper seg veldig når en jobber sånn. Det synes jeg var morsomt å oppleve!”

Gruppearbeidet og betydningen av gruppetilhørighet kan altså påvirke deltagernes opplevelse av å være en del av noe større. Samtidig uttrykte Albert at det gruppevise arbeidet begrenset innsikten deltagerne fikk av hele prosessen. Han gir uttrykk for at han gjerne skulle hatt mulighet til å lære mer om hva de andre gruppene jobbet med.

Niels mener at deltagelsen på NTSC har gitt han god kjennskap til hvor omfattende slike prosesser kan være og hvor mye fagkunnskap som ligger til grunn for det som blir gjort. Han syntes det var interessant å oppdage hvor nødvendig det var å samarbeide på tvers av kompetanse og ansvarsområder, og at det i virkelige situasjoner er viktig at folk er spesialister på hver sine felt:

"Ingen kan bygge romferge alene, men til sammen så kan man gjøre det!"

Niels presiserer også at prosesskunnskap og autentisk erfaring med avansert teknologi og forskning henger nøye sammen med faglig innsikt:

” (...) selv om du ikke sender opp en rakett etter å ha vært der, og selv om du ikke gjør noe praktisk ut av det du har holdt på med, så har du en forståelse av hva det er som skal til for å få opp en rakett. Og hvor mange hensyn som skal tas og hvor mye fag du er nødt til å kunne for og kunne si at ok, vi må klarere dette havområdet her. For ellers så kan det gå gærent. Og når jeg så den lille flekken uti havet som var klarert ... Hvis jeg skulle ha gjort det måtte vi ha rydda halve Barentshavet!"

\section{Overføring til egen undervisning}

Kompetanseutvikling kan på ulike måter ha innvirkning på lærernes egen praksis. Lærerne i denne studien mente de hadde fătt lite utbytte med konkret og direkte overføringsverdi, som undervisningsmateriale og forslag til labaktiviteter. I intervjuene kom det likevel frem at fagkunnskap, ny innsikt og erfaringer tilførte undervisningen nye kvaliteter. Kurserfaringene kan tas med inn i egen praksis både direkte og indirekte, og både erfaringer og konkret kunnskap oppleves som betydningsfulle.

\section{Direkte overføring}

Niels mener at selve kunnskapen han har med seg fra Teachers' Space Camp er lett overførbar i form av nettsider eller bøker. Han har fătt flere ideer i forhold til videreutvikling av undervisningsopplegg med mer teknisk innhold som også kan gi utfordringer for de sterkeste elevene. Han har allerede gjennomført et mindre prosjekt med raketter, noe han mener han aldri ville ha gjort hvis han ikke hadde deltatt på NTSC.

Gjennom økt faglig kunnskap opplever Lise at hun kan svare på mer av det elevene spør om og hun assosierer lettere fysikken i skolen med verden utenfor. Hun likte å få helt konkrete eksempler på hvordan metoder og innhold i skolefysikken kan relateres til det "ekte" forskere og ingeniører gjør, som å forklare nødvendigheten av å tegne "free-body-diagram" i mekanikken:

"Elevene syntes det var ei grei forklaring. For da var det ikke bare jeg som var teit lærer, men de bruker det faktisk ute i den virkelige verden. Han (rakettforskeren) som egentlig kan ta det i hodet. Så den likte jeg!” 
Albert mener også at erfaringene fra NTSC har gjort det lettere for han å finne igjen fysikken i ulike sammenhenger og kunne bruke dette i faglig arbeid med elevene:

”Du får et veldig godt bilde av hvor mye fysikk det er i sånne ting. Det er ikke noe vanskelig å begrunne overfor elevene hvorfor man holder på med dette her."

Marie synes den økte kompetanse innenfor fagfeltet sammen med økt innsikt i den teknologiske prosessen gjør at hun kan gi bedre undervisning til egne elever:

"Når du klarer å se det for deg selv så er det enklere å fortelle om det enn hvis du bare har lest og ikke helt har forstått sammenhengen på alle små detaljer."

\section{Indirekte overføringsverdi: innsikt og erfaringer}

Gjennom samtalene med lærerne identifiserte vi en indirekte overføringsverdi av kurset som lærerne selv ikke umiddelbart fokuserte på som vesentlig for egen undervisning. Den indirekte overføringen er avhengig av selv å ha vært deltagende i et komplekst forskningsmiljø. Nils, for eksempel, finner bøkene og nettressurser fra NTSC som gode hjelpemidler til å ta med seg kunnskap inn i eget klasserom, men mener likevel at disse ressursene i seg selv er ikke nok. Opplevelsen av å ha deltatt i noe autentisk og virkelig er også viktig, og denne erfaringen vil han ta med seg inn i egen undervisning.

Marie har også brukt erfaringene sine i undervisningen. Hun har fortalt om sine opplevelser og erfaringer og synes det er lettere både å fortelle om det og å undervise emnet i ettertid.

Selv om Albert var mest opptatt av det faglige utbyttet likte også han å få innblikk i en annen kultur, i ting som han ikke kunne så mye om fra før. Dette har han kunnet snakke om i klasserommet:

"Det er morsomt å fortelle om raketten, det at den gikk så djevelsk høyt og at vi varsla russerne, og ... ikke sant?"

Ved å ha deltatt i praktisk prosjektarbeid mener Albert det er mulig gjøre egen undervisning mer konkret. Det er likevel vanskelig å ta det videre ut til egne elever:

-"et sånt kontrollrom, du kommer jo aldri i nærheten av noe sånt."

Overføringsverdien fra Space Camp til skolen oppfatter han derfor som noe begrenset og mener at overføring til egen undervisning stort sett har vært på anekdotenivå.

Lise synes derimot at de små dryppene av praktisk erfaring, praktisk bruk av fysikken har vært viktige for hva hun har tatt med seg inn i klasserommet. Hun assosierer mer med verden utenfor klasserommet og kan blant annet i større grad vise elevene hvilke muligheter de har videre:

”Det er kanskje mer troverdig når jeg faktisk har gjort det selv og ikke bare refererer til andre. (...) Plutselig så assosierer jeg ting som jeg opplevde der i forhold til tema som jeg underviser. Men det er ikke fordi jeg har planlagt det. Det blir litt krydder her og der. Dette gir kanskje mer kredibilitet blant elevene?”

Lise legger vekt på at siden hun er ganske fersk som lærer er slike opplevelser viktige for å bygge en base av kunnskap og erfaringer. Dette bidrar til en slags erfaringsbank, "en bank med erfaringer som jeg kan bruke til å konkretisere ting.” Hun mener også at det var viktig å få anledning til å jobbe med et reelle problemstillinger i en autentisk teknologisk prosess:

”Ikke bare være på en skolelab og jobbe med sånt modellutstyr og ting som ikke virker og hvor du egentlig ikke har det verktøyet du trenger og sånn." 


\section{DISKUSJON OG KONKLUSJON}

Studien presentert i denne artikkelen bygger på ett enkelt kurstilbud for lærere, og antall informanter er begrenset. Resultatene er derfor ikke nødvendigvis overførbare til lærere mer generelt og til alle typer tilsvarende etterutdanningstiltak for lærere. Sett i sammenheng med annen litteratur på feltet gir likevel resultatene grunnlag for innspill til debatten om hva som bør inngå i kompetanseutvikling for lærere i naturfagene. Dette baserer seg på at studien identifiserer ulike former for utbytte lærere $k a n$ ha av en gitt type etterutdanningstiltak, og gir derfor grunnlag for en analytisk generaliserbarhet (Yin, 2003).

De fire lærerne som fungerte som informanter i denne studien er alle faglig orienterte. De deltok på NTSC for å tilegne seg relevant og oppdatert fagkunnskap, og var godt fornøyde med det faglig utbyttet av kurset. Lærernes utbytte synes likevel å ha flere fasetter enn ren fagkunnskap. De forteller om ulike former for faglig utbytte, som i denne studien er kategorisert som en innholdskomponent, en prosesskomponent og en affektiv komponent. Før kurset var deltagerne mest opptatt av innholdskomponenten, og det er også denne de fremhever ved evalueringen ved kursavslutningen og i spørreskjema. Økt produktkunnskap er rapportert fra flere studier av tilsvarende tiltak for lærere, se for eksempel Westerlund m. fl (2002), Dresner og Worley (2006) og Brown og Melear (2006). Lærerne i vår studie rapporterer i tillegg om økt selvtillit og tro på egen kunnskap som et viktig utbytte. Gjennom å fordype seg $\mathrm{i}$ et faglig tema sammen med lærerkolleger og faglige eksperter har de styrket sin identitet som fagpersoner som har noe å bidra med til elevene. Dette samsvarer med resultatene til Sadler m.fl (2010), som identifiserer produktkunnskap og selvtillit som to av de mest fremtredende formene for læringsutbytte i sin gjennomgang av 11 ulike studier av lærere som deltar i naturvitenskapelige praksisfellesskap.

I denne studien identifiserer vi i tillegg et utbytte vi har kalt teknologisk prosesskunnskap. Dette er en form for kursutbytte det har vært lite fokus på når det gjelder kompetanseheving for lærere. Tidligere studier av læring i tilsvarende praksisfellesskap er i hovedsak rettet mot prinsipielle aspekter av forskningsprosessen, naturvitenskapelig metode og utforskende arbeidsmåter i skolen (se f.eks Friedrichsen, Munford, \& Orgill, 2006; Sadler, m.fl., 2010; Westerlund, m.fl., 2002). Lærerne som deltok i denne studien viser til andre former for prosesskunnskap, nemlig innsikt i og erfaring med en kompleks teknologisk prosess som del av en autentisk virksomhet innen moderne naturvitenskap. De peker på at dette har hatt innvirkning på hvordan de i ettertid har kunnet bruke egenerfarte eksempler og episoder som del av egen undervisning i fysikk og naturfag. Gjennom deltagelsen på NTSC fikk de erfaring med arbeidet i alle ledd av en rakettoperasjon, fra oppkopling av elektroniske sensorer til signalbehandling og sikkerhetsprosedyrer. Dette er vesentlige aspekter av moderne naturvitenskapelig forskning. Lærerne erfarer betydningen av de teknologiske prosessene og kunnskap knyttet til disse, og hvor nødvendig det er med samarbeid der alle involverte drar sin del av lasset. For forskere og ingeniører er dette realistisk, mens det for lærere kan oppfattes som mindre tilfredsstillende. Dette blir tatt opp av en av lærerne som deltok i studien.

Det er i stor grad kompleksiteten i denne teknologiske prosesskunnskapen lærerne fokuserer på og finner spennende å oppleve. Denne opplevelsen skiller seg fra erfaringer fra mange etter- og videreutdanningskurs hvor faginnholdet og arbeidsmetoder er forenklet og tilpasset klasserommet og elevenes faglige nivå. I stedet får lærerne på dette kurset innsikt i en reell teknologisk og vitenskapelig virksomhet og hvordan arbeidslivet kan arte seg for ingeniører og forskere. Dette er kunnskap som kan synes som vanskelig å overføre til egen undervisning. Resultatene fra studien tyder likevel på at det setter lærerne bedre i stand til å formidle erfaringer til elever gjennom fortellinger og anekdoter, knytte emner opp mot selvopplevde episoder og på denne måten gjøre undervisningen inspirerende og mer virkelighetsnær.

Selv om det meste av kursinnholdet i følge lærerne selv ikke lar seg overføre direkte til egen undervisning forteller de likevel om økt faglig selvtillit, økt motivasjon, økt fagkunnskap og erfaringer fra 
et spennende forskningsfelt, og hvordan dette har betydning for deres egen virksomhet som lærere. Dette tyder på at overføringsverdien til egen undervisning er indirekte, men reell. Lærerne kan gjennom sin egen erfaring og selvopplevde eksempler bidra til å styrke både elevenes faglige kunnskap og deres forståelse for relevansen av naturvitenskapelig kunnskap.

Lærerne som deltar på kurset denne studien omhandler deltar i liten grad i utviklingen av et forskningsprosjekt. Det meste av det de gjør må følge detaljerte retningslinjer og prosedyrer, mens utfordringene de møter handler mer om praktisk problemløsning og innhenting av informasjon for å kunne fullføre en del av et større prosjekt. Dette utgjør en viktig del av et moderne høyteknologisk forskningsprosjekt. De får erfaring med en prosess som representerer en reell arbeidssituasjon for ingeniører og teknologer som inngår i slike prosjekter, og i mange sammenhenger også for forskere. Dette er erfaring som kan oppfattes som mer relevant i forhold til skoleelever som vurderer et framtidig teknologisk yrke, og som lærerne i større grad kan formidle og inspirere til i skolen.

Realfaglærere må ha ha god kjennskap til fagets betydning for og anvendelse i verden utenfor klasserommet. Denne kunnskapen kommer ikke via forelesninger og fagbøker, men må erfares gjennom aktiv deltagelse i autentiske miljøer. Mange av aktivitetene lærerne deltar i under sin deltagelse på NTSC er organisert som gruppearbeid der de arbeider under veiledning av forskere og ingeniører, i det Wenger (1998) har kalt for praksisfellesskap ("community of practice"). Kursdeltagerne omtaler en læringsprosess som av Lave og Wenger (1991) omtales som "legitimate peripheral participation", der de gjennom samarbeid med mer erfarne forskere og ingeniører blir løftet opp og fram videre i arbeidet. Disse opplevelsene oppfatter lærerne som positive og viktige for deres utbytte av kurset. Dette samsvarer med rapportert utbytte fra tilsvarende kurs for studenter der autentiske aktiviteter og samarbeid med ekspertert var i fokus (se f.eks Beare, 2007; Etkina, Lawrence, \& Charney, 1999). I denne sammenhengen tyder deltagernes erfaringer på at de gjennom denne måten å jobbe på tilegner seg fagkunnskap og ferdigheter, og de får innsikt i et for dem nytt fagområde. Kunnskapene erverves i den konteksten den utvikles og brukes, i tråd med et situert syn på læring (Brown, Collins \& Duguid, 1989). For å imøtekomme dagens behov for å gjøre naturfagene realistiske og virkelighetsnære, bør derfor perspektivet på læreres kunnskapsbehov utvides til å inkludere teknologisk prosesskunnskap og reelle kontekster hvor slik kunnskap opptrer.

NTSC er av relativt kort varighet sammenlignet med andre tiltak som er gjort for å gi lærere erfaring med autentisk forskning (Sadler, m.fl., 2010). Denne undersøkelsen viser at kurs med varighet på under en uke, som NTSC, også kan være viktig for å bygge læreres kompetanse innen teknologibasert naturvitenskap. Kortere, mindre ressurskrevende og mer gjennomførbare tiltak som f.eks NTSC ser ut til å kunne ha stor verdi for lærerne. Dette er i samsvar med andre studier som også viser til effekt av fagspesifikke kurs av kortere varighet (Lydon \& King, 2009).

I nordisk sammenheng fremstår kurs av formatet til NTSC som realistisk i forhold til deltagelse og gjennomføring enn mer ressurskrevende tiltak av flere ukers eller måneders varighet. Samtidig har de utdanningspolitiske føringene nevnt innledningsvis ført til mindre etterspørsel etter denne typen faglige kurs. Dette har dermed gitt mindre rom for lærernes individuelle utviklingsønsker i faglig retning. En utfordring for fysikklærere i Norge er at de gjerne bare er en eller to som underviser dette faget på skolen. Romteknologi er et spesielt emne og læreren er ofte i utgangspunktet spesialisten på skolen innenfor dette. Eventuell oppfølging må derfor komme utenfra, antagelig i likhet med all form for faglig oppdatering, faglig orientert etter- og videreutdanning for fysikklærere og andre spesialister. Derfor er det viktig at kursene bidrar til faglig selvtillit og motivasjon, ettersom lærerne i stor grad må regne med å være selvgående innenfor emnet.

Dette handler om lærernes identitet som fagpersoner. Kontakt med lærere ved andre skoler og eksperter i relevante fagmiljø er vesentlig for å opprettholde og videreutvikle lærerens faglige identitet. Lærere påvirkes av mange ulike faktorer i forhold til utvikling av identitet som lærer, stadige end- 
ringer i samfunnet og skiftende kontekst i form av læreplaner og retningslinjer (Beijaard, Meijer, \& Verloop, 2004). For å kunne formidle naturvitenskap som en viktig og relevant del av samfunnet bør lærere derfor kunne få de erfaringene som gir dem identitet ikke bare som lærer, men også som fagperson og fagformidler, der "fag" inkluderer både produktet og prosessen - samt rollen faget har i samfunnet.

Flere har pekt på at aktiv deltagelse i naturvitenskapelig forskning gir lærere innsikt og fordypning i naturvitenskapelig kultur (se f.eks. Knight, 2002; Westerlund, m.fl., 2002). Det å stille spørsmål, lære teknikker, bruke naturvitenskapelig språk, analysere data, presentere resultater, og være sammen med forskere og ingeniører er en del av denne kulturen. Studien presentert i denne artikkelen har vist at lærerne også kan ha stort utbytte av å delta i et komplekst, høyteknologisk miljø, selv om de ikke deltar i et forskningsprosjekt som sådan. De får likevel innsikt i den teknologiske prosesskunnskapen som er en vesentlig del av moderne forskning, og mange av momentene nevnt i Westerlund m.fl (2002) er relevante også for den mer tekniske delen av naturvitenskapelig forskning. Gjennom deltagelsen blir lærerne en del av et forskningsteknisk fellesskap og lærer gjennom en autentisk opplevelse. Slike opplevelser, som også inkluderer den teknologiske siden av moderne forskningspraksis, bør altså utgjøre en viktig del av tilbud om etter- og videreutdanning for lærere i alle naturvitenskapene.

\section{REFERANSER}

Abd-El-Khalick, F., BouJaoude, S., Duschl, R., Lederman, N. G., Mamlok-Naaman, R., Hofstein, A., m.fl. (2004). Inquiry in science education: International perspectives. Science Education, 88(3), 397-419.

Beare, R. (2007). Investigation into the Potential of Investigative Projects Involving Powerful Robotic Telescopes to Inspire Interest in Science. [Research Report]. International Journal of Science Education, 29(3), 279-306.

Beijaard, D., Meijer, P. C., \& Verloop, N. (2004). Reconsidering research on teachers' professional identity. Teaching and Teacher Education, 2O(2), 107-128.

Brown, J. S., Collins, A., \& Duguid, P. (1989). Situated cognition and the culture of learning. Educational Researcher, 18(1), 32-42.

Brown, S. L., \& Melear, C. T. (2006). Investigation of secondary science teachers' belies and practices after authentic inquiry-based experiences. Journal of Research in Science Teaching, 43(9), 938962.

Dresner, M., \& Worley, E. (2006). Teacher Research Experiences, Partnerships With Scientists, and Teacher Networks Sustaining Factors From Professional Development. Journal of Science Teacher Education, 17(1), 1-14.

Etkina, E., Lawrence, M., \& Charney, J. (1999). Introducing astrophysics research to high school students. Physics education, 34(5), 300-305.

Friedrichsen, P. M., Munford, D., \& Orgill, M. (2006). Brokering at the boundary: A prospective science teacher engages students in inquiry. Science Teacher Education, 9o(3), 22.

Hagen, A., \& Nyen, T. (2009). Kompetanse - for hvem?: sluttrapport fra evalueringen av "Kompetanse for utvikling. Strategi for kompetanseutvikling i grunnopplæringen 2005-2008”. Oslo: Forskningsstiftelsen FAFO.

Hattie, J. (2009). Visible learning: a synthesis of over 800 meta-analyses relating to achievement. London: Routledge.

Knight, P. (2002). A systemic approach to professional development: learning as practice. Teaching and Teacher Education, 18(3), 229-241.

Kunnskapsdepartementet (2006). Et Felles løft for realfagene: tiltaksplan 2006. Oslo: Kunnskapsdepartementet.

Kunnskapsdepartementet (2010). Realfag for framtida: strategi for styrking av realfag og teknologi 2010-2014. Oslo: Kunnskapsdepartementet. 
Lave, J., \& Wenger, E. (1991). Situated learning: legitimate peripheral participation. Cambridge: Cambridge University Press.

Lydon, S., \& King, C. (2009). Can a single, short continuing professional development workshop cause change in the classroom? Professional Development in Education, 35(1), 63-82.

Mehli, H. (2008). Lærersamlinger ved Narom/Andøya Rakettskytefelt - Opplevelser fra kurs gjennomført $i 2005$ og 2006. Andenes: Narom.

Mehli, H., \& Bungum, B. (2012). A space for learning: How teachers benefit from participating in a professional community of space technology. Submitted.

Merriam, S. B. (1998). Qualitative Research and Case Study Applications in Education. San Fransisco: Jossey-Bass Publishers.

Millar, R., \& Osborne, J. (1998). Beyond 2000. Science education for the future. London: Nuffield Foundation.

Osborne, J., \& Dillon, J. (2008). Science education in Europe: Critical reflections. London: Nuffield Foundation.

Robson, C. (2002). Real world research: a resource for social scientists and practitioner-researchers. Oxford: Blackwell.

Roth, W.-M. (1995). Authentic school science: knowing and learning in open-inquiry science laboratories. Dordrecht: Kluwer Academic.

Sadler, T. D., Burgin, S., McKinney, L., \& Ponjuan, L. (2010). Learning science through research apprenticeships: A critical review of the literature. Journal of Research in Science Teaching, 47(3), 235-256.

Schwartz, R. S., Lederman, N. G., \& Crawford, B. A. (2004). Developing views of nature of science in an authentic context: An explicit approach to bridging the gap between nature of science and scientific inquiry. Science Education, 88(4), 610-645.

Sjøberg, S. (2009). Naturfag som allmenndannelse: en kritisk fagdidaktikk. Oslo: Gyldendal akademisk.

Utdannings- og forskningsdepartementet (2002). Realfag, naturligvis: strategi for styrking av realfagene 2002-2007.

Wenger, E. (1998). Communities of practice: Learning, meaning and identity (1 ed.): Cambridge University Press.

Westerlund, J. F., Garcia, D. M., Koke, J. R., Taylor, T. A., \& Mason, D. S. (2002). Summer Scientific Research for Teachers: The Experience and its Effect. Journal of Science Teacher Education, 13(1), 63-83.

Yin, R. K. (2003). Case study research: design and methods: Sage Publications. 